\section{Intern ational}

Journal of

Medical

and Surgical Sciences

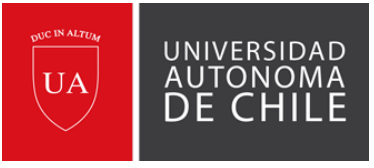

\title{
Alterations in serum uric acid values in a sample of Nigerian pregnant women.
}

\author{
Chisom Clara Wagbara ${ }^{1} \&$ Chizindu Akubudike Alikor. ${ }^{1}$
}

\begin{abstract}
Introduction: Serum uric acid level is an important prognostic variable in pregnancy as subjects with preeclampsia have elevated serum uric acid levels. Methods: The concentrations of serum uric acid were investigated in 100 women of which 75 were pregnant women and categorized into 3 groups of 25 each, based on their trimesters of pregnancy and 25 non-pregnant women, which served as control. Results: In the first trimester, the mean values of uric acid were 122 $\mu \mathrm{mol} / \mathrm{L}$ with a decrease in the levels of uric acid when compared with the control levels of $308 \mu \mathrm{mol} / \mathrm{L}(p<0.05)$. In the second trimester, the values of uric acid were $199 \mathrm{umol} / \mathrm{I}$ with a significant $(p<0.05)$ decrease in the levels of uric acid when compared with the controls. In the third trimester of pregnancy, the values of uric acid were $360 \mu \mathrm{mol} / \mathrm{L}$. There was a significant $(p<0.05)$ increase in the level of uric acid when compared with the controls. Conclusion: The progressive increase in the levels of uric acid through the trimesters of pregnancy suggests an impairment in uric acid excretion, may be with concomitant increase in renal tubular re-absorption of uric acid, thereby leading to hyperuricaemia.

Keywords: Serum uric acid, pregnant women, antenatal clinic.
\end{abstract}

\section{INTRODUCTION}

Pregnancy is the clutching of one or more embryos or foetuses by mammals in their wombs. Pregnancy in women is estimated to last for about 40 weeks, and this is between the time of last menstrual cycle and birth. Gestation is purely the period of pregnancy measured in weeks and medical practitioners have divided this period into three trimesters. The first trimester period, which is $0-13$ weeks, carries the highest risk of miscarriage. In the second trimester; which is $13-26$ weeks, the development of the foetus can begin to be monitored and assessed. The third trimester of pregnancy; which is 26 - 40 weeks, marks the beginning of viability (Ashwood, 1992).

In pregnancy, a woman undergoes dramatic changes, which is both physiological and hormonal. The kidney is also faced with tremendous anatomical and physiological changes (Ashwood, 1999). Changes in fluid distribution within the period of pregnancy, in turn, prompt an increase in glomerular filtration rate (GFR) and lower plasma creatinine. These changes go with alteration in the concentration of many plasma constituents (Chesley, 1951). The values of estrogen, corticosteroids, progesterone and placental lactogen are large during pregnancy, hence they affect various metabolic, physiological and endocrine systems in the woman's body. Physiological changes occurring in pregnancy involve almost all organ systems and the kidney is not an exception. As a result of these changes, many of the laboratory reference intervals of non-pregnant women are not appropriate for pregnant women (Ashwood, 1999).

The kidneys are the primary means of eliminating waste products of metabolism that are no longer needed by the body. These include urea (from metabolism of amino acids), creatinine (from muscle creatinine), uric acid (from nucleic acid metabolism) and metabolism of various hormones. The renal system goes through marked 
changes in function during pregnancy due to hormonal effects, increased metabolic load of the foetus and outflow obstruction of the ureters by the enlarging uterus. Renal function can be evaluated by the determination of urea, creatinine and uric acid levels in serum/plasma. The effect of renal failure on body fluids include generalized oedema, acidosis, high concentration of protein nitrogen, especially concentrations of urea, creatinine and other nitrogenous end products of amino acid or protein metabolism; a condition known as ureamia, which results from the failure of the kidneys to maintain adequate excretory, regulatory and endocrine functions (Burtis \& Ashwood, 1999). So, the clinical chemistry laboratory has an important role in the management of pregnancy.

Uric acid is a marker of oxidative stress, tissue injury and renal dysfunction; it is possible that uric acid merely identifies a more severe form of preeclampsia. However, increased uric acid is also an independent risk factor for cardiovascular disease and is proposed to mediate altered vascular function and inflammation (Johnson et al., 2003; Shi et al, 2003). In addition, increased uric acid has been shown to cause specific adverse effects on blood pressure in studies of non-pregnant rats (Mazzali et al., 2001).

The aim of this study was to determine the pattern of serum uric acid across gestation in pregnant women attending ante-natal clinic at Rumuolumeni Health Center, Rumuolumeni, Obio/Akpor, Rivers State, Nigeria.

\section{MATERIALS AND METHODS}

A total of 100 subjects were used for this study; 75 were pregnant women attending ante-natal clinic in Rumuolumeni Health Center, Rumuolumeni, Obio/Akpor, Rivers State, Nigeria; while the other 25 women were randomly selected non-pregnant women within the clinic environment, which served as control. The pregnant women were divided into three groups of 25 each, based on the trimester of their pregnancies. Relevant information about pregnancy and health status of the subjects was obtained, after they gave their informed consent.

$5 \mathrm{ml}$ blood were collected by venous puncture using a 5 $\mathrm{ml}$ sterile syringe and needle. The blood was dispensed into clean dry tubes, allowed to clot for about 15 minutes at room temperature, then centrifuged at 3000rpm for 5 minutes and the serum was harvested into clean dry screw-capped bottles.

Chemicals and reagents used include the following: $14 \%$ Sodium Carbonate, $50 \%$ Acetic acid, conc. $\mathrm{H}_{2} \mathrm{SO}_{4}$, Phosphoric Acid, Diacetyl monoxime thiosemicarbazide, phenyl mercuric acid, $10 \%$ Sodium tungstate, Lithium carbonate, N/12 $\mathrm{H}_{2} \mathrm{SO}_{4}$, Phosphotungstic acid, $\mathrm{FeCl}_{3} \cdot 6 \mathrm{H}_{2} \mathrm{O}$, distilled water, Analar gra- de picric acid, $0.75 \mathrm{~N}$ Sodium hydroxide and other widespread laboratory reagents. The instruments used include spectrophotometer, refrigerator, water bath, centrifuge and other common laboratory apparatuses.

Serum uric acid was assayed by phosphotungstic acid method. Preparation of reagents was done using standard laboratory procedure and the reagents used were of analytical grade. The technique for uric acid estimation has two stages.

Stage I: $8 \mathrm{ml} \mathrm{N} / 12 \mathrm{H}_{2} \mathrm{SO}_{4}$ was mixed with $1 \mathrm{ml}$ serum and $1 \mathrm{ml} 10 \%$ sodium tungstate, then spun in a centrifuge at 3000 rpm for 5 minutes.

Stage II: $3 \mathrm{ml}$ of supernatant was added to the tube labeled test, $3 \mathrm{ml}$ uric acid standard was added to the test tube labeled standard and $3 \mathrm{ml}$ distilled water was added to the test tube labeled blank. Then, $1 \mathrm{ml}$ of $14 \%$ sodium carbonate and $1 \mathrm{ml}$ of phosphotungstic acid were added to each of test, standard (Std) and blank test tubes. They were left for 15 minutes at room temperature and absorbance was read at $680 \mathrm{~nm}$ against reagent blank. The concentration of uric acid was calculated using the expression:

Uric acid $(\mu \mathrm{mol} / \mathrm{l})=\frac{A_{\text {test }}}{A_{\text {Std }}} \times$ Concentration of standard $(600 \mu \mathrm{mol} / \mathrm{l})$

Where A represent absorbance.

Data was presented as mean \pm standard deviation, and analyzed statistically using Analysis of Variance (ANOVA). Then, where applicable, Duncan Multiple Range test was used to determine level of significance $(p<0.05)$.

\section{RESULTS}

Table 1 shows the mean levels of serum uric acid in pregnant women attending ante-natal clinic at Rumuolumeni Health Center, Rumuolumeni, Obio/Akpor, Rivers State, Nigeria, at different trimesters of pregnancy and non-pregnant women as control. These results showed that there was a progressive increase in the levels of uric acid across the 3 trimesters of pregnancy. There was a significant $(p<0.05)$ decrease in the levels of uric acid during 1 st and 2 nd trimesters, while there was a significant $(p<0.05)$ increase in the level of uric acid in the 3rd trimester of pregnancy, when compared with the control.

Table 2 shows the age distribution of pregnant women across three trimesters, attending ante-natal clinic at Rumuolumeni Health Center, Rumuolumeni, Obio/Akpor, Rivers State, Nigeria and the control. 
Table 1: Table showing levels of serum uric acid in pregnant women at Rumuolumeni Health Center, Rumuolumeni, Obio/Akpor, Rivers State, Nigeria.

\begin{tabular}{|l|c|c|c|c|}
\hline Parameters & Control & 1st trimester & 2nd trimester & 3rd trimester \\
\hline Serum Uric acid $(\mu \mathrm{mol} / \mathrm{l})$ & $308.0 \pm 26$ & $122.0 \pm 23^{*}$ & $199.0 \pm 32 *$ & $360.0 \pm 27^{*}$ \\
\hline
\end{tabular}

Values are means $\pm S D$, where $S D=$ standard deviation, $n=100$.

Values with asterisk $(*)$ are significantly different from the control at $p<0.05$.

Table 2: Age distribution of pregnant women attending ante-natal clinic at Rumuolumeni Health Center, Rumuolumeni, Obio/Akpor, Rivers State, Nigeria.

\begin{tabular}{|l|c|c|c|c|c|}
\hline \multicolumn{5}{|c|}{ Pregnancy stages and percentage age of subjects } \\
\hline Age Group & 1st trimester & 2nd trimester & 3rd trimester & Control & \% Age \\
\hline $16-20$ & 7 & 4 & 8 & 8 & 27 \\
\hline $21-25$ & 3 & 3 & 5 & 2 & 13 \\
\hline $26-30$ & 9 & 11 & 7 & 6 & 33 \\
\hline $31-35$ & 4 & 6 & 3 & 8 & 21 \\
\hline $36-40$ & 2 & 1 & 2 & 1 & 6 \\
\hline
\end{tabular}

\section{DISCUSSION}

The clinical laboratory has an important role to play in the management of women during pregnancy. When pregnancy occurs, a woman undergoes several physiological and biochemical changes such as hematological, hormonal, renal function, etc. As a result of these changes, many of the laboratory reference intervals for non-pregnant women are not appropriate for pregnant women. Pregnancy includes widely diverging physiological changes, including changes in renal function, which can be exaggerated or altered by environmental conditions and genetic factors. However, full appreciation of the pattern of changes may only be achieved through serial investigation, in which each subject acts as its own control (Shanahan \& Hofer, 2005). The renal changes that involve enlargement of the kidney (Leve et al., 2010) are attributed in the number of cells during pregnancy. The hormonal changes that take place during pregnancy may affect the handling of electrolyte, volume expansion and resultant vasodilatation (Vendlinski et al, 2012). All these may consistently influence the cardiovascular system.

The findings of other researchers showed that elevated serum uric acid concentration is a marker of oxidative stress tissue injury dysfunction and that it is an independent risk factor for cardiovascular disease (Johnson et al., 2003; Shi et al., 2003), giving rise to high blood pressure. During uncomplicated pregnancies, serum uric acid concentrations decrease by $25 \%-35 \%$ in early pregnancy but increase throughout pregnancy until towards the end of pregnancy when the concentra- tions approach non-pregnancy levels. In this study, we found an elevated serum uric acid level during the $3^{\text {rd }}$ trimester, which is consistent with other studies (Kang et al., 2004). It was proposed that those pregnancy-mediated changes in serum uric acids are primarily the result of altered renal handling.

Increased serum uric acid in pre-eclampsia are secondary to reduced renal urate clearance because of renal dysfunction (Conrad et al., 1999) and also were due to increased xanthine oxidase activity (Many et al., 1996). Increased serum uric acid level is a key clinical feature of pre-eclampsia; higher levels correlate with significant maternal and fetal morbidity and mortality. The cause of hyperuricaemia and its specific role in the pathogenesis of pre-eclampsia, however, remains unclear. Nevertheless, there have been recent data supporting a potential pathogenic role in the hypertension and endothelial cell dysfunction of pre-eclampsia (Lam et al., 2005). It is also possible that increased serum uric acid value may indicate the presence of undiagnosed sub-clinical renal disease in some subjects and this might increase the risk for pre-eclampsia.

Pre-eclampsia is a common disorder of pregnancy characterized by high blood pressure and proteinuria, posing a serious health risk to mother and fetus. Increased serum uric acid is an early and characteristic feature of preeclampsia, which helps to differentiate the disorder from essential and other chronic forms of pre-existing hypertension, which complicate pregnancy (Bramham et al., 2014). The implication of an increase in serum uric acid was observed in 20 pregnant women 
complicated by pre-eclampsia and 22 normal pregnant women at 23-28 weeks of gestation. The mean serum uric acid level in women with pre-eclampsia was significantly higher than in the normal pregnant women (Suzuki et al, 2001). It was also shown by Johnson et al. (2013) that elevated level of serum uric acid could be attributed to the well-documented decline of GFR in pre-eclampsia. However, we could not establish if the pregnant women with hyperuricaemia had pre-eclampsia, due to the limitation that this study did not include determination of blood pressure and serum protein levels.

\section{CONCLUSION}

There was a progressive increase in the levels of uric acid across the 3 trimesters of pregnancy, as shown in this study. There was significant increase in serum uric acid level in the $3^{\text {rd }}$ trimester of pregnancy when compared with the controls.

\section{REFERENCES}

Ashwood ER. Evaluating health and maturation of the unborn: the role of the clinical laboratory. Clin Chem. 1992; 38(8): 1523 - 1529.

Ashwood ER. In: Burtis CA, Ashwood ER (Eds.). Tietz textbook of Clinical chemistry, 3rd ed. Philadelphia, USA: W.B. Saunders; 1999.

Bramham K, Parnell B, Nelson-Piercy C, Seed PT, Poston L, Chappell LC. Chronic hypertension and pregnancy outcomes: systematic review and meta-analysis. BMJ. 2014;348: g2301.

Burtis CA, Ashwood ER (Eds.). Tietz Fundamentals of Clinical Chemistry, 3rd ed. Philadelphia: W.B. Saunders Company; 1999.

Chesley LC. Kidney Function in the Normal and Toxemic Pregnant Woman. Med. Clin. North. Am. 1951;35(3): 669-714.

Conrad KP, Kerchner L, Mosher MD. Plasma and 24-h NO(x) and cGMP during normal pregnancy and preeclampsia in women on a reduced $\mathrm{NO}(\mathrm{x})$ diet. Am J Physiol. 1999;277(1):48-57.

Johnson RJ, Kang DH, Feig D, Kivlighn S, Kanellis J, Watanabe S. Is there a pathogenetic role for uric acid in hypertension and cardiovascular and renal disease? Hypertension 2003;41(6):1183-90.

Kang DH, Finch J, Nakagawa T, Karumanchi SA, Kanellis J, Granger J, Johnson RJ. Uric acid, endothelial dysfunction and pre-eclampsia: searching for a pathogenetic link. J Hypertens. 2004;22(2):229-35.

Lam C, Lim K, Kang D, Ananth S. Uric acid and preeclampsia. Semin Nephrol. 2005;25(1): 56-60.

Leve L, Kerr DC, Shaw D, Ge X, Neiderhiser J, Scaramella L, Reid J, Conger R, Reiss D. Infant pathways to externalizing behavior: evidence of genotype x environment interaction. Child Dev. 2010;81(1):340-356.

Many A, Westerhausen-Larson A, Kanbour-Shakir A, Roberts JM. Xanthine oxidase/dehydrogenase is present in human placenta. Placenta 1996;17(5-6):361-365.

Mazzali M, Hughes J, Kim YG, Jefferson JA, Kang DH, Gordon KL, Watanabe S, Nakagawa T, Lan HY, Johnson RJ. Elevated uric acid increases blood pressure in the rat by a novel crystal-independent mechanism. Hypertension 2001;38: 1101-6.

Shanahan MJ, Hofer SM. Social context in gene-environment interactions: retrospect and prospect. J Gerontol B Psychol Sci Soc Sci. 2005;60(1): 65-76.

Shi Y, Evans JE, Rock KL. Molecular identification of a danger signal that alerts the immune system to dying cells. Nature 2003;425(6957):51621.

Suzuki S, Yoneyama Y, Sawa R, Otsubo Y, Takeuchi T, Araki T. Relation between Serum Uric Acid and Plasma Adenosine Levels in Women with Preeclampsia. Gynecol Obstet Invest. 2001;51(3): 169-172.

Vendlinski MK, Lemery-Chalfant K, Essex MJ, Hill H. Genetic risk by experience interaction for childbirth internalizing problems: converging evidence across multiple methods. J Child Psychol Psychiatry 2012;52(5):607-618. 